Research paper

\title{
Decline of Fraxinus excelsior L. in parks of Saint Petersburg: Who is to blame - Hymenoscyphus fraxineus or Diplodia spp.?
}

\author{
Dmitrii A. Shabunin ${ }^{1}$, Andrey V. Selikhovkin ${ }^{2,3^{*}}$, Elena Yu. \\ Varentsova $^{2}$ and Dmitry L. Musolin ${ }^{2}$
}

\begin{abstract}
Shabunin, D.A., Selikhovkin, A.V., Varentsova, E.Yu., Musolin, D.L. 2020. Decline of Fraxinus excelsior L. in parks of Saint Petersburg: Who is to blame - Hymenoscyphus fraxineus or Diplodia spp.? - Forestry Studies | Metsanduslikud Uurimused 73, 43-51, ISSN 1406-9954. Journal homepage: http://mi.emu.ee/forestry.studies
\end{abstract}

\begin{abstract}
The weakening and decline of European ash Fraxinus excelsior L. and other ash species have been recorded at different locations in the suburbs of Saint Petersburg, Russia. During the summer of 2019 and spring of 2020, samples from leaves, petioles, and shoots were collected from the weakened and declining ash trees in three parks in Pushkin and Gatchina and maintained in humid chambers to induce the fructification of fungi. In total, 30 taxa of micromycetes belonging to 23 genera were identified using methods of light microscopy. Hymenoscyphus fraxineus, a putative agent of ash dieback, was not recorded in the samples collected in the crowns of trees, but only on the petioles of the fallen leaves in spring. Out of all the micromycetes recorded, only coelomycetes from the genus Diplodia Fr. (in particular, D. mutila) can damage the branches of ash trees and, thus, be considered pathogenic. It is likely that $H$. fraxineus opens "the entry of infection" and Diplodia spp. cause the major weakening and decline of branches. The data obtained can significantly change our understanding of the causes of ash dieback and possible methods of ash stand preservation. The reason for the low pathogenicity and activity of $H$. fraxineus, as well as the possible role of ascomycetes Diplodia spp. in the dieback of ash stands requires further research.
\end{abstract}

Key words: ash dieback, European ash, Ascomycota, tree health, invasive tree fungal pathogen, urban greening.

Authors' addresses: ${ }^{1}$ Department of Forest Selection, Saint Petersburg Forestry Research Institute, Institutskiy pr., 21, 194021, Saint Petersburg, Russian Federation; ${ }^{2}$ Department of Forest Protection, Wood Science and Game Management, Saint Petersburg State Forest Technical University, Institutskiy per., 5, 194021, Saint Petersburg, Russian Federation; ${ }^{3}$ Department of Biogeography and Environmental Protection, Saint Petersburg State University, Universitetskaya nab., 7-9, 199034, Saint Petersburg, Russian Federation; *e-mail: a.selikhovkin@mail.ru

\section{Introduction}

Urban and suburban green spaces fulfill a very important function of creating a comfortable living environment. In large European cities and urban agglomerations, tree stands are usually formed by species of woody plants that are not characteristic of the surrounding local forest ecosystems. This is conditioned by the specific features of the urban environment; predominant$l y$, the aesthetic requirements and the im- 
pact of the negative anthropogenic factors, such as air and soil pollution (Nowak et al., 2006; Alekseyev et al., 2019). For example, city parks and urban plantings of Saint Petersburg, Russia, are mostly planted by the small-leaved lime Tilia cordata Mill., Norway maple Acer platanoides L., silver birch Betula pendula Roth, Berlin poplar Populus $\times$ berolinensis Dippel, green ash Fraxinus pennsylvanica Marsh, English oak Quercus robur L., and European white elm Ulmus laevis Pall., whereas the forest ecosystems of Saint Petersburg suburbs and the surrounding Leningrad Province are dominated by Scots pine Pinus sylvestris L., Norway spruce Picea abies (L.) H. Karst., a few species of birch Betula spp., European aspen Populus tremula L., and grey alder Alnus incana (L.) Moench (Moschenikova, 2011). The specific composition of woody vegetation and a strong influence of the factors compromising the resistance of woody plantings make these plantings highly susceptible to invasive pathogens and pests in the urban environment (Selikhovkin et al., 2018, 2020).

Saint Petersburg is a big cultural center that attracts millions of tourists every year and also serves as a transportation hub. As a result, the process of invasion of pathogens and arthropod pests of woody plants is very intensive here (Shabunin et al., 2012; Musolin et al., 2017; Selikhovkin et al., 2018, 2020). The ascomycete Hymenoscyphus fraxineus (T. Kowalski) Baral, Queloz \& Hosoya (anamorph of Chalara fraxinea) causing ash dieback is one of the phytopathogenic invaders that recently reached the city. During the last 20 years, this fungus has rapidly spread over the most of Europe causing fast and almost complete death of ash stands everywhere it was recorded (Enderle et al., 2017; Vasaitis \& Enderle, 2017). This species was recorded in Saint Petersburg as well, in particular, at Dudergof Heights in the drying-off stands of European ash Fraxinus excelsior L. (Shabunin et al., 2012).

During recent routine surveys of parks and urban plantings in Saint Petersburg and its suburbs, deterioration of the health conditions of ash trees was noted: individual shoots were dying off and individual trees or groups of trees died in Aleksandrovsky and Babolovsky Parks of Pushkin district of Saint Petersburg, as well as in Gatchina Palace Park in Leningrad Province (Figure 1). The dying trees often had symptoms characteristic of ash dieback induced by $H$. fraxineus (Vasaitis \& Enderle, 2017). Thus, it was suggested that invasive $H$. fraxineus might be a pathogenic agent causing death of ash trees in these parks.

The aim of the study was to evaluate a possible role of $H$. fraxineus as well as other pathogenic fungi in the death of ash trees in the parks of Saint Petersburg and its suburbs.

\section{Material and Methods}

In the second half of July and in August of 2018 and 2019, and in May 2020 surveys were conducted in Aleksandrovsky Park (59 43'30" N, 30²2'20" E) and Babolovsky Parks (59 $43^{\prime} 03^{\prime \prime}$ N, $30^{\circ} 22^{\prime} 11^{\prime \prime}$ E) of Pushkin district of Saint Petersburg as well as in Gatchina Palace Park (59 $33^{\prime} 51^{\prime \prime} \mathrm{N}$, $30^{\circ} 06^{\prime} 49^{\prime \prime}$ E) in Leningrad Province (Figure 1). We evaluated the health conditions of European ash F. excelsior trees (aged 30 years and older; breast height diameter of $20 \mathrm{~cm}$ and more). In Aleksandrovsky Park, 37 ash trees that looked the most weakened were checked and evaluated, in Babolovsky Park - 35 trees, and in Palace Park in Gatchina - 88 ash trees (Figure 2). In Aleksandrovsky and Babolovsky Parks, ash dieback tended to have a cluster character when diseased trees formed a group of near-growing ash trees (Figure 2).

To evaluate the health condition of ash trees, we used standardized categories adopted in the Russian Federation for forest pathology surveys using six categories: (I) healthy trees, (II) weakened trees, (III) heavily weakened trees, (IV) drying-out 


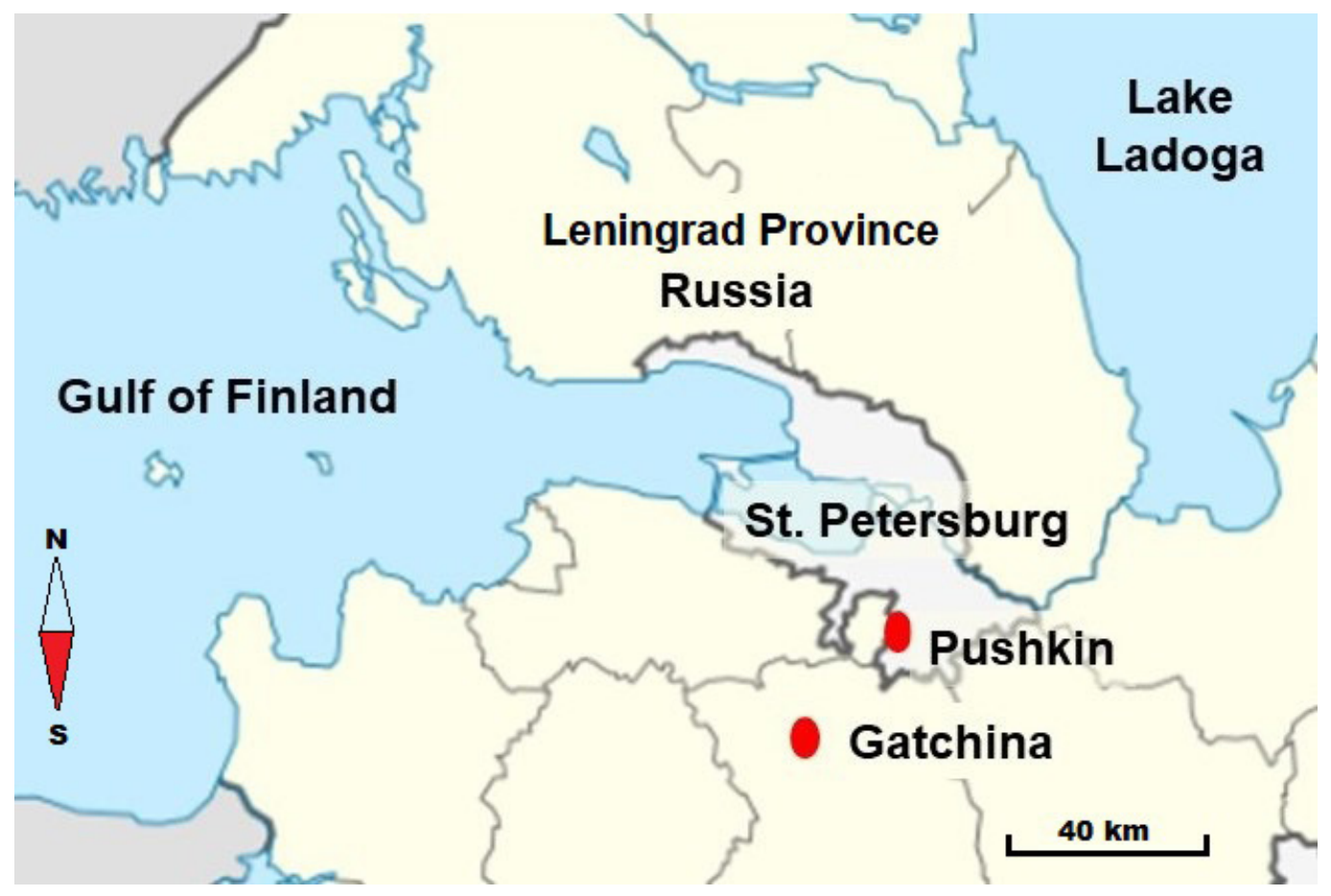

Figure 1. Location of the parks surveyed in this study.

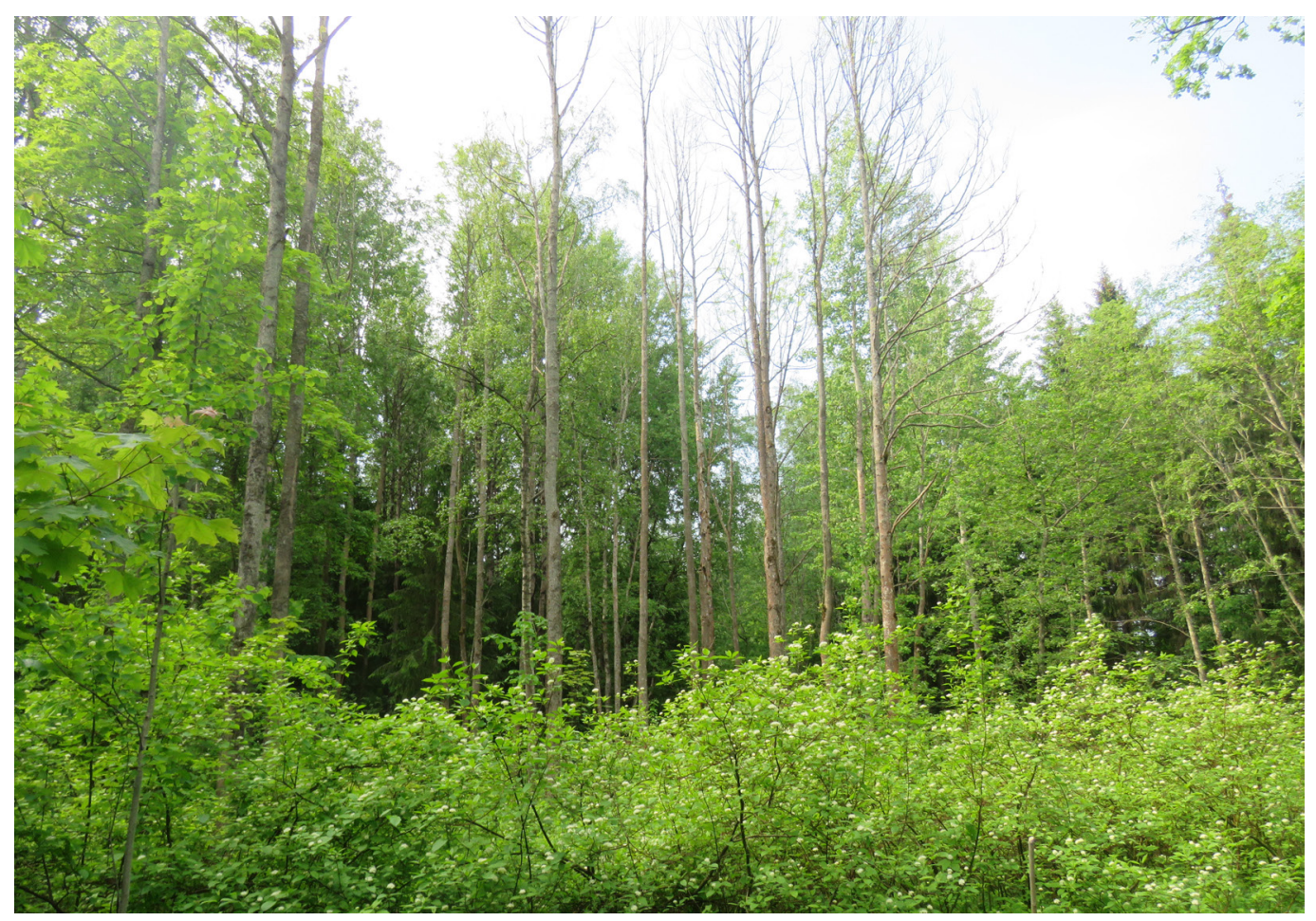

Figure 2. Group weakening and decline of European ash Fraxinus excelsior trees in Babolovsky Park (photo by Bui Dinh Duc, with permission). 
trees, (V) trees that had died during the current year, and (VI) trees that had died during the previous year (categories $\mathrm{V}$ and VI were combined in our surveys; Mozolevskaya et al., 1984).

In 2019, a focused study was conducted in the same locations with a purpose to detect the presence and identify phytopathogenic fungi causing deterioration of the ash trees' health status. Three times during the summer season (on June 26, July 25, and August 27), we collected dried and damaged shoots with leaves from the lower part of the crown of adult ash trees using a $5.5 \mathrm{~m}$ long rod secateurs. The last year's fallen leaf petioles were collected on July 25,2019 . The next year, the collection of the petioles was repeated on May 27, 2020. In most cases, samples of leaves and shoots

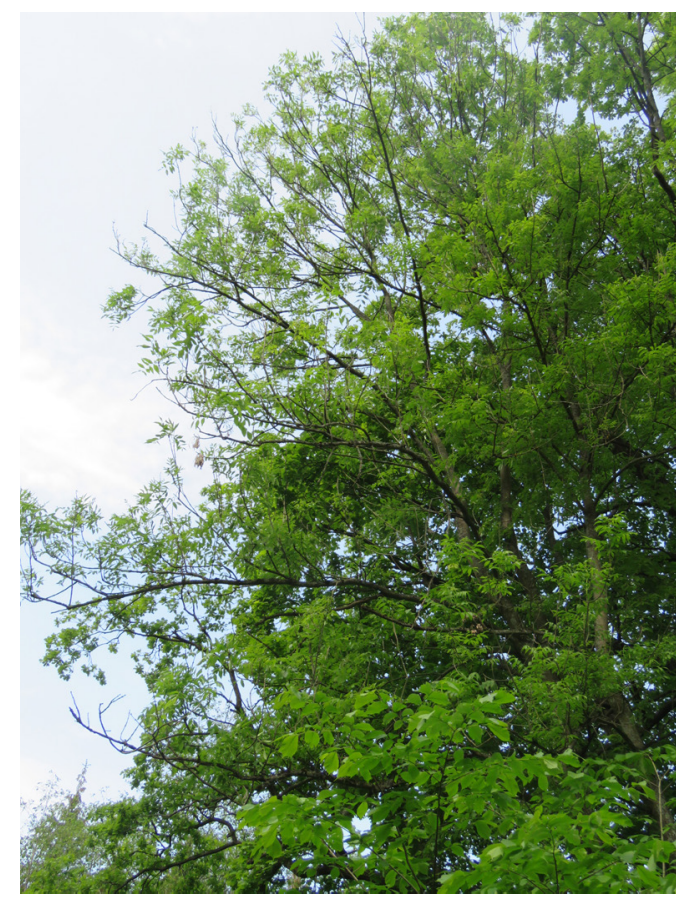

Figure 3. Typical appearance of European ash Fraxinus excelsior of the health category III (heavily weakened trees) from which samples were collected for the identification of pathogenic micromycetes (Aleksandrovsky Park, Pushkin; photo by Andrey V. Selikhovkin). from crowns were collected from the same trees on all three dates. In total, $30 \mathrm{sam}$ ples were collected from 20 trees (namely, 11 samples from 9 trees in Aleksandrovsky Park, 5 samples from 3 trees in Babolovsky Park, and 14 samples from 8 trees in Palace Park). Samples were collected mostly from heavily weakened trees (health category III: 23 samples from 17 trees; Figure 3), weakened trees (health category II: 5 samples from 2 trees) followed by drying-out trees (health category IV: 2 samples from 1 tree).

The sampled leaves, petioles, and shoots were studied in a laboratory using stereomicroscope MBS-9. Then, the samples were incubated in a humid chamber under room conditions with regular monitoring of the emerging fruit bodies of micromycetes. After 3-4 weeks of incubation, in most cases, all samples were covered with sterile mycelium and the observations ceased.

The identification of fungal species was carried out during the monitoring of the appearance of micromycetes fruiting in the humid chamber using morphological characteristics under the upright microscope Motic BA400. The appearance of the putative pathogen $H$. fraxineus was monitored by observing the development of fungi in the humid chamber, as it was previously revealed that in the humid chamber fruiting of the imperfect stage of $H$. fraxineus develops quite quickly (Shabunin et al., 2012; Musolin et al., 2017).

\section{Results}

In all three parks (Aleksandrovsky, Babolovsky, and Palace Park), the group weakening and death of European ash trees having the symptoms characteristic of ash dieback caused by $H$. fraxineus on the crowns' periphery were observed. All the surveyed ash trees had symptoms of weakening, including the drying-out of peripheral shoots, individual branches, 
Table 1. The health state of Fraxinus excelsior trees in the parks of Pushkin and Gatchina according to the surveys of 2018-2019.

\begin{tabular}{|c|c|c|c|c|}
\hline \multirow[t]{2}{*}{ Health state categories of trees } & \multirow[t]{2}{*}{ Score } & \multicolumn{3}{|c|}{$\begin{array}{l}\text { Number of trees in each category } \\
\text { for each park }(\%)\end{array}$} \\
\hline & & Aleksandrovsky Park & Babolovsky Park & Palace Park \\
\hline I (healthy trees) & 1 & $0(0.0)$ & $0(0.0)$ & $0(0.0)$ \\
\hline II (weakened trees) & 2 & $5(13.5)$ & $3(8.6)$ & $16(18.2)$ \\
\hline III (heavily weakened trees) & 3 & $20(54.1)$ & $12(34.3)$ & $54(61.4)$ \\
\hline IV (drying-out trees) & 4 & $10(27.0)$ & $15(42.8)$ & $15(17.0)$ \\
\hline $\begin{array}{l}\text { V (trees that had died during the } \\
\text { current year) and VI (trees that } \\
\text { had died during the previous year) } \\
\text { combined }\end{array}$ & 5 and 6 & $2(5.4)$ & $5(14.3)$ & $3(3.4)$ \\
\hline Total & & $37(100)$ & $35(100)$ & $88(100)$ \\
\hline $\begin{array}{l}\text { Weighted score of the tree health } \\
\text { category }\end{array}$ & & 3.25 & 3.70 & 3.07 \\
\hline
\end{tabular}

and, in some cases, significant sections of the crowns. Dead trees were recorded in all parks (Table 1). On average, the health state score of ash stands was between heavily weakened trees (category III) and drying-out trees (IV), with the situation in Babolovsky Park being the worst (Table 1).

Monitoring of the incubation of the collected samples in the humid chamber allowed to identify 30 taxa of micromycetes belonging to 24 genera (Table 2). We recorded 19 taxa of micromycetes belonging to 14 genera from the leaf tissues, 13 species (10 genera) from petioles, and 9 taxa (8 genera) from shoots (Table 2). All the registered fungal species are typical for the ash mycobiota. The coelomycetes of the genus Diplodia were found throughout the entire observation period and were the most prevalent species.

The ascomycete $H$. fraxineus, a putative agent of ash dieback, was not found in the collected samples from the crowns of F. excelsior. The fungus was not also found on petioles of the fallen leaves collected on July 25, 2019. Only in the next spring, typical dark brown pseudosclerotial tissues were observed. During the subsequent incubation in a humid chamber, fruiting bodies of the fungus appeared on the tissue samples that had overwintered on soil and had been collected on May 27, 2020.

In contrast, fungi of the genus Diplodia were found in all three parks and during all three months in 2019, although not at each sampling collection session (Table 2). Based on morphological characteristics, the samples collected in the beginning and in the middle of summer were identified as Diplodia mutila (Fr.) Mont. (Figure 4). In the samples collected in August 2019, conidia had a slightly larger size and somewhat different pigmentation. These specimens were identified only up to the genus level (Diplodia sp.). All other fungi detected on the collected samples do not induce observed crown damage (Table 2).

\section{Discussion}

The conducted survey demonstrated that symptoms of the weakening and dieback of ash that are usually associated with $H$. fraxineus were found in many ash trees and in all three parks. In fact, there were absolutely no healthy ash trees among surveyed trees, and the average tree health score ranged from 3.07 (heavily weakened trees) to 3.7 (almost drying-out trees). However, in our samples from tree crowns, $H$. fraxineus was not found in any 
Table 2. Micromycetes from the leaves, petioles, and shoots of Fraxinus excelsior cultivated in a humidified incubator.

\begin{tabular}{|c|c|c|c|}
\hline \multirow{2}{*}{$\begin{array}{l}\text { Date of } \\
\text { sample } \\
\text { collection }\end{array}$} & \multicolumn{3}{|c|}{ Location of sampling and identified micromycetes } \\
\hline & Aleksandrovsky Park & Babolovsky Park & Palace Park \\
\hline $\begin{array}{l}\text { June 26, } \\
2019\end{array}$ & $\begin{array}{l}\text { "Codinaea sp. } \\
\text { ** Diplodia mutila (Fr.) Mont. }\end{array}$ & $\begin{array}{l}\text { *Phomopsis sp. } \\
\text { *Stachybotrys sp. }\end{array}$ & $\begin{array}{l}{ }^{*} \text { Coniothyrium sp. } \\
{ }^{* *} \text { Diplodia mutila (Fr.) Mont. }\end{array}$ \\
\hline $\begin{array}{l}\text { July 25, } \\
2019\end{array}$ & $\begin{array}{l}{ }^{*} \text { Cladosporium herbarum (on } \\
\text { galls of Dasineura fraxinea) }\end{array}$ & $\begin{array}{l}\text { *Cladosporium herbarum (on } \\
\text { galls of Dasineura fraxinea) } \\
\text { *Phyllactinia fraxini (DC.) } \\
\text { Fuss }\end{array}$ & 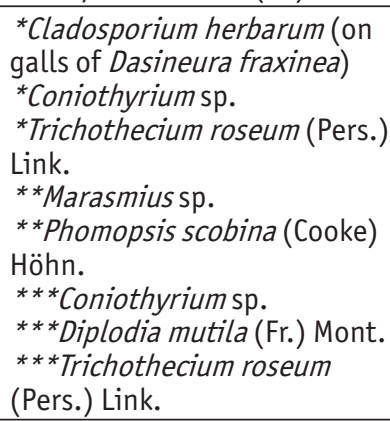 \\
\hline $\begin{array}{l}\text { August } \\
27,2019\end{array}$ & $\begin{array}{l}\text { *Alternaria sp. } \\
\text { *Botrytis sp. ( } B \text {. cinerea?) } \\
\text { *Cladosporium spp. } \\
\text { *Gonatobotrys flava Bonord. } \\
\text { *Hansfordia sp. } \\
\text { *Harsia sp. } \\
\text { *Periconia cookei E.W. Mason } \\
\text { et M.B. Ells } \\
\text { *Periconia sp. } \\
\text { *Phomopsis scobina (Cooke) } \\
\text { Höhn. } \\
\text { *Stachybotrys sp. } \\
\text { *Trichothecium roseum (Pers.) } \\
\text { Link. } \\
\text { ***Diplodia sp. } \\
\text { ***Gliomastix sp. }\end{array}$ & 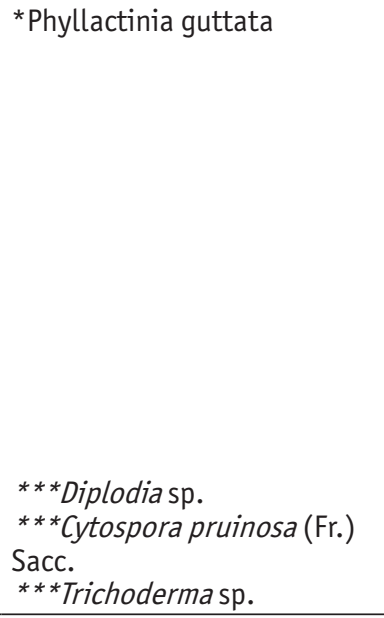 & $\begin{array}{l}\text { *Alternaria sp. } \\
\text { *Cladosporium spp. } \\
\text { *Gliomastix sp. } \\
\text { *Periconia sp. } \\
\text { *Phomopsis scobina (Cooke) } \\
\text { Höhn. } \\
\text { *Phyllactinia sp. (possibly, P. } \\
\text { guttata) }\end{array}$ \\
\hline $\begin{array}{l}\text { May 27, } \\
2020\end{array}$ & & $\begin{array}{l}{ }^{*} \text { Alternaria spp. } \\
{ }^{*} \text { Cladosporium sp. } \\
*{ }^{*} \text { Fusicladium fraxini Aderh. } \\
{ }^{* *} \text { Hymenoscyphus fraxineus } \\
\text { (T. Kowalski) Baral, Queloz \& } \\
\text { Hosoya }\end{array}$ & $\begin{array}{l}{ }^{*} \text { Alternaria sp. } \\
{ }^{*} \text { Cladosporium macrocarpum } \\
\text { Preuss } \\
{ }^{*} \text { Cladosporium sp. } \\
{ }^{*} \text { Coniothyrium sp. } \\
{ }^{*} \text { Dictyochaeta sp. } \\
{ }^{* *} \text { Fusicladium fraxini Aderh. } \\
{ }^{*} \text { Gyrothrix ramosa Zucconi \& } \\
\text { Onofri } \\
{ }^{*} \text { Hymenoscyphus fraxineus } \\
\text { (T. Kowalski) Baral, Queloz \& } \\
\text { Hosoya } \\
\text { **Periconia cookeiE.W. Mason } \\
\text { \& M.B. Ellis } \\
* * \text { Periconia sp. }\end{array}$ \\
\hline
\end{tabular}

Notes: $^{*}$ - sampled on leaves; ${ }^{* *}$ - sampled on petioles; ${ }^{* * *}$ - sampled on shoots. 

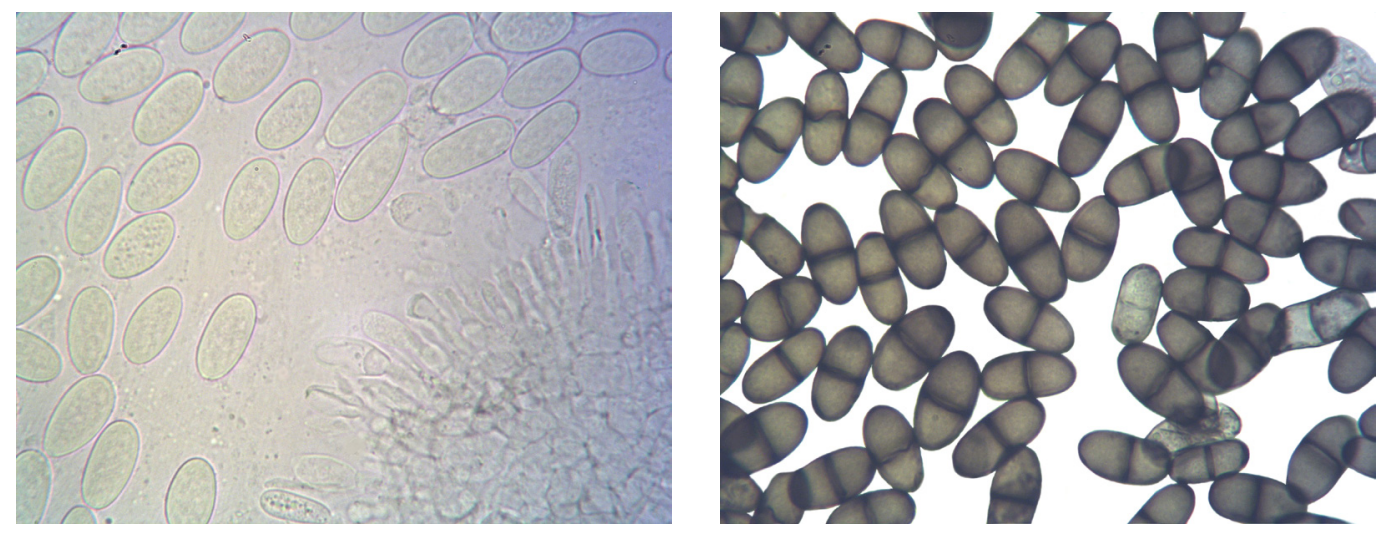

Figure 4. Conidia (left), conidia and conidiophores (right) of Diplodia mutila (Fr.) Mont. from shoots of Fraxinus excelsior collected on July 25, 2019 in Aleksandrovsky Park, Pushkin (left) and Palace Park, Gatchina (right) (photo by Dmitrii A. Shabunin).

of the surveyed park and on any date. The fungus was found only on the petioles of fallen leaves in spring. This finding suggests that the role of the highly pathogenic $H$. fraxineus in the weakening and dieback of ash crowns in the surveyed parks is questionable.

Out of the 30 taxa of micromycetes belonging to the 23 genera recorded in this study (Table 2), only coelomycetes from the genus Diplodia Fr. can cause shoot blight of such a kind (Merezhko, 1980). A few species of Diplodia are known to be associated with ash species (Alves et al., 2014). Among them, D. mutila is the most reported species (Alves et al., 2014; Kowalski et al., 2016). We identified this species among the samples collected in June and July 2019 in Aleksandrovsky and Babolovsky Park (Table 2). In the samples collected in August 2019 in all three parks, Diplodia sp. was also present, but we failed to identify particular species. On average, Diplodia sp. was recorded on $37.5-50.0 \%$ ash trees in the survey of 2019.

It is interesting to note that phytopathogenic Diplodia spp. were not recorded in the ash stands severely damaged by $H$. fraxineus in the Tellerman Experimental Forestry located in Voronezh Province, Russia (Kolganikhina, 2018).

The pathogenicity of $H$. fraxineus is known to depend on various factors, in- cluding landscape characteristics (Grosdidier et al., 2020). However, the data obtained in Pushkin and Gatchina can significantly change our understanding of the causes of ash dieback and possible methods for the preservation of ash stands. The local foci of ash dieback caused by $H$. fraxineus were recorded in ash plantations at Dudergof Heights (Shabunin et al., 2012) which is only $14-18 \mathrm{~km}$ away from Pushkin and Gatchina. It is also known that the presence of $H$. fraxineus was confirmed in 2011 in Saint Petersburg, where ash leaf petioles with apothecia of the fungus were found in the Botanical Garden (Dendrarium) of Saint Petersburg State Forestry Technical University and Botanical Garden of the Botanical Institute of the Russian Academy of Sciences (Musolin et al., 2014, 2017). Despite the pathogen's presence, the decline of ash trees was not obvious at that time and is not observed now. These foci of $H$. fraxineus are only 30-50 km northward from Pushkin and Gatchina. Given the fairly close distance between all these points, the low activity and pathogenicity of $H$. fraxineus in Pushkin and Gatchina are interesting facts that require further research.

Under the circumstances when $H$. fraxineus was not recorded in the samples collected from the ash trees with the symptoms 
of dieback, the presence of Diplodia spp. can indicate that these pathogenic ascomycetes cause the weakening and death of ash trees in the surveyed parks. However, data are scarce on the pathogenicity of Diplodia spp. developing on deciduous woody plants in general and on ash in Russia in particular. There is evidence of the pathogenicity of these fungi to conifers, but the issue is poorly studied in respect of ash species (Merezhko, 1980; Zhukov et al., 2013). Elsewhere, it has been reported that young ash trees died because of spring frosts followed by infection by Diplodia mutila, Gloeosporidiella turgida (Berk. \& Broome) B. Sutton, and Phomopsis scobina (Cooke) Höhn. in Austria in 2005 (Cech, 2006). Also, D. mutila was isolated from the affected shoots of ash in Poland (Przybył, 2002; Kowalski \& Łukomska, 2005) as well as in other European countries (Alves et al., 2014).

\section{Conclusions}

The pathogenic ascomycete $H$. fraxineus was not found in the samples collected from the crowns of the weakened and heavily damaged $F$. excelsior trees in the parks of Pushkin and Gatchina. It was recorded only on the overwintered petioles of fallen leaves. At the same time, the pathogenic ascomycetes Diplodia spp. and, in particular, D. mutila colonized almost all shoots sampled. Under such circumstances, we assume that $H$. fraxineus opens "the entry of infection", and Diplodia spp. cause the main weakening and decline of branches.

The data obtained suggest that there are some specific factors that inhibit the activity and/or spreading of $H$. fraxineus and, thus, promote dominance of other phytopathogenic species of fungi. The factors determining the low activity of $H$. fraxineus as well as the role of Diplodia spp. in the weakening of $F$. excelsior stands in and around Saint Petersburg require further research.
Acknowledgements. The work of D.L.M. was partly supported by the Russian Foundation for Basic Research (grant \#17-0401486). We sincerely acknowledge Ekaterina A. Tsytsulina for reading the paper and making constructive comments.

\section{References}

Alekseyev, A.S., Selikhovkin, A.V. Khodachek, O.A. 2019. Factors that influence the health conditions of the coniferous stands in recreation stands. (Факторы, воздействующие на состояние хвойных древостоев в рекреационных насаждениях). - Regional Economy and Development of Territories, 1 (13), 128-133. (In Russian).

Alves, A., Linaldeddu, B.T., Deidda, A., Scanu, B., Phillips, A.J.L. 2014. The complex of Diplodia species associated with Fraxinus and some other woody hosts in Italy and Portugal. Fungal Diversity, 67, 143-156. https://doi. org/10.1007/s13225-014-0282-9.

Cech, T.L. 2006. Striking damaging agents on forest trees in 2005. - Forstschutz Aktuell, 35, 6-7. (In German with English summary).

Enderle, R., Pliūra, A., Vasaitis, R. (eds.) 2017. Advances in Ash Dieback Research - and Some Other Invasive Diseases of Trees. - Baltic Forestry, 23, 1-333.

Grosdidier, M., Scordia, T., Ioos, R., Marçais, B. 2020. Landscape epidemiology of ash dieback. - Journal of Ecology, 108, 1789-1799. https:/ / doi.org/10.1111/1365-2745.13383.

Kolganikhina, G.B. 2018. Pathogenic and saprotrophic fungi on ash in the stands of the Tellerman Experimental Forestry. - Forestry Bulletin, 22(6), 40-48. (In Russian with English summary).

Kowalski, T., Kraj, W., Bednarz, B. 2016. Fungi on stems and twigs in initial and advanced stages of dieback of European ash (Fraxinus excelsior) in Poland. - European Journal of Forest Research, 135, 565-579. https://doi. org/10.1007/s10342-016-0955-x.

Kowalski, T., Łukomska, A. 2005. Study on ash dying in the Włoszczowa Forest Unit stands. - Acta Agrobotanica, 59 (2), 429-440. (In Polish with English summary).

Merezhko, T.A. 1980. Fungal Flora of Ukraine. Spheropsidal Fungi. (Флора грибов Украины. Сферопсидальные грибы). Kiev, Naukova Dumka. 208 pp. (In Russian). 
Moschenikova, N.B. 2011. Assessment of the ecological state of green spaces of St. Petersburg. (Оценка экологического состояния зелёных насаждений Санкт-Петербурга). - Abstract of the Dissertation for the degree of Candidate of biological sciences. Moscow, Moscow State University of Forest. 19 pp. (In Russian).

Mozolevskaya, E.G., Kataev, O.A., Sokolova, E.S. 1984. Methods of Forest Pathological Surveys of Foci of Stem Pests and Forest Diseases. (Методы лесопатологического обследования очагов стволовых вредителей и болезней леса). Moscow, Forest Industry. 152 pp. (In Russian).

Musolin, D.L., Bulgakov, T.S., Selikhovkin, A.V., Adamson, K., Drenkhan, R., Vasaitis, R. 2014. Dothistroma septosporum, D. pini and Hymenoscyphus fraxineus (Ascomycota) are pathogens of woody plants that cause serious concern in Europe. (Dothistroma septosporum, D. pini и Hymenoscyphus fraxineus (Ascomycota), патогены древесных растений, вызывающие серьезную озабоченность в Европе). - Musolin, D.L., Selikhovkin, A.V. (eds.). The Kataev Memorial Readings - VII. Pests and Diseases of Woody Plants in Russia. Proceedings of International Conference, Russia, Nov. 2014. St. Petersburg, 54-55. (In Russian).

Musolin, D.L., Selikhovkin, A.V., Shabunin, D.A., Zviagintsev, V.B., Baranchikov, Y.N. 2017. Between ash dieback and emerald ash borer: Two Asian invaders in Russia and the future of ash in Europe. - Baltic Forestry, 23(1), 316-333.

Nowak, D.J., Crane, D.E., Stevens, J.C. 2006. Air pollution removal by urban trees and shrubs in the United States. - Urban Forestry \& Urban Greening, 4, 115-123. https://doi. org/10.1016/j.ufug.2006.01.007.
Przybył, K. 2002. Fungi associated with necrotic apical parts of Fraxinus excelsior shoots. Forest Pathology, 32, 387-394. https://doi. org/10.1046/j.1439-0329.2002.00301.x.

Selikhovkin, A.V., Baryshnikova, S.V., Denisova, N.V., Timofeeva, Yu.A. 2018. Species composition and population dynamics of dominant dendrophagous moths (Lepidoptera) in St. Petersburg and its environs. - Entomological Review, 98(8), 963978.

Selikhovkin, A.V., Drenkhan, R., Mandelstam, M.Yu., Musolin, D.L. 2020. Invasions of insect pests and fungal pathogens of woody plants into the northwestern part of European Russia. - Vestnik of Saint Petersburg University, Earth Sciences, 65(2), 263-283. (In Russian with English summary).

Shabunin, D.A., Semakova, T.A., Davydenko, E.V., Vasaitis, R.A. 2012. Ash decline in the nature monument Dudergof Heights, caused by the fungus Hymenoscyphus pseudoalbidus, and morphological features of its ascospores. - Proceedings of the Saint Petersburg Forest Research Institute, 1-2, 70-79. (In Russian with English summary).

Vasaitis, R., Enderle, R. (eds.). 2017. Dieback of European Ash (Fraxinus spp.) - Consequences and Guidelines for Sustainable Management. Uppsala, Swedish University of Agricultural Sciences. 299 pp.

Zhukov, A.M., Gninenko, Y.I., Zhukov, P.D. 2013. Dangerous and Poorly Studied Diseases of Coniferous Trees in Forests of Russia. (Опасные малоизученные болезни хвойных пород в лесах России). 2nd ed. Pushkino, VNIILM. 128 pp. (In Russian). 